\title{
Legal Aspects of Identity Transactions Involving Entities with Foreign Elements: ICT Technologies and Issues of the Tax Burden
}

\author{
IGOR SAMSIN ${ }^{1}$, NATALIIA KOVALKO ${ }^{2}$, ANATOLIY KOVALENKO ${ }^{3}$, DMYTRO ZABZALIUK ${ }^{4}$, \\ KATERYNA KURANDO ${ }^{5}$ \\ ${ }^{1}$ Department of Constitutional, Administrative and Financial Law, KHMELNYTSKY UNIVERSITY OF \\ MANAGEMENT AND LAW, UKRAINE. E-mail:v.sam@ukr.net \\ ${ }^{2}$ Department of Financial Law, TARAS SHEVCHENKO NATIONAL UNIVERSITY OF KYIV, UKRAINE. \\ ${ }^{3}$ Department of Public Law Disciplines, KYIV INTERNATIONAL UNIVERSITY, UKRAINE. \\ ${ }^{4}$ Department of Theory and History of State and Law, Constitutional and International Law, LVIV STATE \\ UNIVERSITY OF INTERNAL AFFAIRS, UKRAINE. \\ ${ }^{5}$ Department of Administrative and Economic Law, ODESSA I.I. MECHNIKOV NATIONAL UNIVERSITY, UKRAINE.
}

\begin{abstract}
Legal analysis of transaction authentication with the participation of legal entities with a foreign element (LEFE) is interesting not only in disclosing theoretical and practical issues but also with difficulties and several features regarding foreign law application. The purpose of the article is to find the correct procedure for notarization of transactions on the territory of Ukraine with the participation of LEFE. In the research process, the authors combine theoretical developments and legislative instructions with practical experience of notarization. The research is based on four statements, which are confirmed during the study, contain a detailed description of the nuances to avoid possible errors and also offer to use a list of documents required to certification an undisputed transaction in Ukraine. The result of the article and its novelty is a detailed study of the actions of a notary in the certification of transactions involving LEFE, the presentation of a visual algorithm based on the above statements, namely: before the notary certificate it is necessary to determine whether the subjects of the transaction are LEFE; if a legal entity is established under the legislation of another state, then its civil and legal capacity is determined by the personal law of the state of such legal entity; there are certain restrictions on the activities of LEFE in Ukraine. The authors reviewed the recent changes in the taxation in Ukraine of LEFE, which must be taken into account; proposed the use of ICT technologies in notaries, what can not only simplify the process, help avoid subjective mistakes, but also open up new opportunities to streamline transactions involving entities with foreign elements.
\end{abstract}

Keywords: foreign law, foreign legal entity, legalization of documents, taxation.

JEL Classification: K12, E62, H87

Received: 28 March 2021

Accepted: 21 April 2021 


\section{Introduction.}

The legal issues that are the subject of this article are significant not only for the notarial community of Ukraine. Since Ukraine and the international community are increasingly deepening in numerous investment projects, existing migration processes, family ties abroad, and other circumstances influence the definition of the notary as an essential tool for implementing any documentary actions in the international arena circulation. Legal analysis of transaction certificates with the participation of legal entities with a foreign element (LEFE) is interesting not only in terms of disclosure of theoretical and practical issues but first of all, has difficulties and several features regarding the application of foreign law.

While researching several issues related to the notarial process with a foreign element, the authors try to give an algorithm of actions to both the parties to the transaction and the notary of Ukraine. The work's urgency is since the issue is one of the least developed in the theory of the notarial process.

The number of appeals of foreign legal entities to notaries in Ukraine to certify various transactions is growing every year. This is due to multiple factors, including the liberalization of all spheres of society. Therefore, the procedural order for notarial acts on transactions where the party (parties) to the transaction is a foreign element, their features in the notarial process is a topical issue of many generations, as such actions of the notary are closely related to the protection of individuals and legal entities in Ukraine.

\section{Literature review.}

Theoretical and practical aspects of the notarial process in Ukraine have been and remain a relevant topic of research, including such domestic scientists and scholars as S. Fursa (2012), V. Komarov, V. Barankova (2011), Yu. Mytsa (2010) and others.

The current legislation of Ukraine stipulates that a transaction is an action of a person aimed at acquiring, changing or terminating civil rights and obligations. The Civil Code of Ukraine defines that a transaction made in writing is subject to notarization only in cases established by law by the parties' agreement. Notarization of a transaction is carried out by a notary or other official who, by the law, has the right to perform such a notarial act, by making a certification document on the document containing the text of the transaction (Pieprzyca, 2016; Merkulova, 2020).

Notarization may be performed only in such a transaction that meets the general requirements established by law, namely: the content of the transaction may not contradict the Civil Code, other acts of civil law, as well as the moral principles of society. The person who performs the transaction must have the necessary amount of civil capacity, and the transaction itself must be performed in the form prescribed by law.

One of the features of the international notarial process's notarial procedural relations is its connection with a foreign element (Dolynska, 2018; Dorofeeva, 2021). It is the presence of a foreign element in these relations that necessitates the application of material processes to the general rules of notarial acts and the rules of private international law (Rogerson, 2015). It should be noted that the concept of "foreign element" is not the same in all countries. For example, according to the Supreme People's Court of China's interpretation, the term "foreign element" refers to a wide range of foreign or non-domestic factors (Zhang, 2018). Presence in private law relations at least one form of a foreign element is the basis for the application of normative material of private international law (Vasilchenko, 2007; Christie, 2017). Simultaneously, the legal nature of a foreign element is quite problematic for legal science and practice (Barankova, 2011; Nani, 2018). However, the issue of performing notarial acts with a foreign element in Ukrainian science is almost not studied, because in the works of most researchers attention is paid to the notarial process, which is not complicated by a foreign element. The purpose of the article is to find the correct procedure for notarization of transactions on the territory of Ukraine with the participation of LEFE. 


\section{Methods.}

In the process of research, the authors combine theoretical developments and legislative instructions with practical experience of notarization. The study is based on 5 statements, which are explained in detail and confirmed during the study.

\section{Generalization of Main Statements.}

\subsection{Concepts and types of legal entities with a foreign element.}

Statement 1: before the notarization it is necessary to determine whether the subjects of the transaction are legal entities with a foreign element.

There is no clearly defined concept of "foreign legal entity" in the legislation of Ukraine. The general concept of a legal entity is given by the Civil Code of Ukraine (Article 80), where a legal entity is an organization established and registered in the manner prescribed by law. A legal entity is endowed with the civil, and legal capacity may be a plaintiff and defendant in court. However, the Law of Ukraine "On Private International Law" (Article 25) states that the location of a legal entity is the state in which the legal entity is registered or otherwise established following the law of that state. Thus, to be recognized as a foreign legal entity, it is sufficient that it be established under legislation other than the legislation of Ukraine. If it is impossible to establish under which legislation the legal entity is created, the criterion of its executive body's location is applied.

Thus, the Law of Ukraine "On Foreign Economic Activity" to the category of foreign economic entities includes such entities that have a permanent location outside Ukraine. In this case, a foreign business entity's permanent location means the location of its officially registered main governing body (Article 1).

It should be noted that the legislation of Ukraine defines the concept of "foreign enterprise" (Articles 117, 396 of the Commercial Code of Ukraine). Thus, a foreign enterprise is a unitary or corporate enterprise established under the legislation of Ukraine, which operates exclusively based on the property of foreigners or foreign legal entities, or an operating enterprise acquired entirely in the ownership of these persons. The activity of branches, representative offices and other separate subdivisions of enterprises formed under the legislation of other states is carried out on the territory of Ukraine by the legislation of Ukraine. The law provides conditions and procedure for creation, requirements for the organization and operation of foreign enterprises on the regime of foreign investment, other laws.

On the Ukraine territory, enterprises with foreign investments are created and operate in the forms provided by the Ukraine legislation. Constituent documents of enterprises with foreign investment must contain information the relevant organizational and legal forms of enterprises, as well as information on the state affiliation of their founders (participants) (Articles 16, 17 of the Law "On Foreign Investment").

Thus, to determine the list and scope of documents that must be submitted to certify a transaction involving a legal entity with a foreign element, the notary must first establish whether it is really a legal entity established under the laws of another state or a foreign enterprise established based on the property of a foreign legal entity or with the participation of non-residents, but under the legislation of Ukraine.

\subsection{Verification and determination of the scope of the civil capacity and legal capacity of foreign} legal entities. Verification of the credentials of a representative of a foreign legal entity.

Statement 2: if a legal entity is created under the law of another state, then its civil capacity and legal capacity are determined by the state's personal law and such legal entity.

When certifying transactions involving legal entities, the notary must verify the legal entity's civil capacity and legal capacity by reviewing the constituent documents, requesting information from 
other bodies, institutions, and individuals regarding the legal entity. (Article 44 of the Law of Ukraine "On Notaries").

Suppose the submitted constituent documents show that a legal entity is established under the legislation of another state. In that case, the civil capacity and legal capacity of a legal entity are determined by the personal law of such legal entity (Article 26 of the Law "On Private International Law").

For example, foreign business entities confirm their legal status by an extract from the trade, banking or court register. Thus, trade registers in Austria and Germany are kept by the courts; in Switzerland, courts and administrative bodies. An extract from a particular ledger contains the necessary information for stakeholders, including information on the name of the company; type of company (legal form); content of activity; an indication of persons responsible for its activities and persons entitled to sign contracts and other documents; information on fixed capital.

By analogy with the law, a notary in the examination of the evidence of the legal personality of a foreign legal entity may use the rules of Art. 74 of the Law "On Private International Law", which states that at the request of the court hearing the case, with the participation of a foreign legal entity, a foreign legal entity must submit a document proving the legal personality of the legal entity (registration certificate, extract from the trade register etc.).

Thus, the registration of a foreign legal entity is confirmed by an extract from the register of legal entities of the country of origin of the entity, the provision of a certificate of incorporation or a certificate of the prosperity of the company. The extract from the trade register, in particular, indicates the number of the legal entity, the date of its creation, organizational and legal form, location address and data on the authorized capital, registered directors and the executive secretary of the company. For example, in France, information about legal entities is contained in the Register of Businessmen and Companies, in the UK - an extract from the register of companies is issued by Companies House UK (registration service).

When certifying transactions involving a foreign legal entity, the notary must check the information on whether the legal entity is in force or is in the process of liquidation based on statutory documents and information provided by specially authorized bodies.

The founding documents of a legal entity provided to a notary must meet the requirements of the legislation of the country in which such a person is registered. If the law does not stipulate the mandatory presence of founding documents in the company, this provision must be confirmed by a document issued by the registration authority.

If the powers of the head of the company are not specified in the extract from the register, then to confirm them it may be necessary to provide the notary with other internal documents of the legal entity, for example - the minutes of the general meeting of shareholders. It should be noted that the legislation of some states sets the age limit for the head of a legal entity.

Requiring a foreign legal entity to provide the above documents, notaries must take into account the following. Many norms of Ukrainian civil/commercial law are borrowed from foreign law (primarily German and French). Therefore, legal capacity issues, such as limited liability companies and joint-stock companies, are regulated similarly. However, some countries' foreign legislation provides for organizational and legal forms of legal entities, not known to domestic law, establishing special requirements for their creation and operation. For example, joint-stock companies are established in France, Germany, Switzerland and other countries.

Returning to the practical aspect of the certification of transactions with the participation of LEFE, the authors propose to use a list of documents required for the certification of an undisputed transaction in Ukraine (Table 1). 
Table 1. List of documents certifying transactions with the participation of LEFE

\begin{tabular}{|c|c|}
\hline $\begin{array}{l}\text { List of documents for notarization, } \\
\text { if a representative of the legal entity acts } \\
\text { by the power of attorney }\end{array}$ & $\begin{array}{l}\text { List of documents for notarization, } \\
\text { if there is ahead of a foreign legal entity }\end{array}$ \\
\hline $\begin{array}{l}\text { 1. Power of attorney (legalization (apostille), the text } \\
\text { is translated into Ukrainian, the authenticity of the } \\
\text { translator's signature is notarized); } \\
\text { 2. Passport of the representative by power of } \\
\text { attorney and registration number of the taxpayer's } \\
\text { account card (translation of the passport into } \\
\text { Ukrainian, the authenticity of the translator's } \\
\text { signature is notarized); } \\
\text { 3. The original of the legalized (apostille) extract from } \\
\text { the trade, banking or court register to confirm the } \\
\text { scope of the civil capacity and legal capacity of the } \\
\text { legal entity, the text translated into Ukrainian, the } \\
\text { authenticity of the translator's signature is notarized, } \\
\text { etc. }\end{array}$ & $\begin{array}{l}\text { 1. Originals of constituent documents of a legal entity } \\
\text { depending on the organizational and legal form (the } \\
\text { text is translated into Ukrainian, the authenticity of } \\
\text { the translator's signature is notarized); } \\
\text { 2. A document confirming the authority of the head to } \\
\text { commit a transaction; } \\
\text { 3. Minutes of the general meeting of shareholders } \\
\text { (founders) or the decision on the intention of the legal } \\
\text { entity to make transactions, preferably with essential } \\
\text { conditions; } \\
\text { 4. The original of the legalized (apostille) extract from } \\
\text { the commercial, banking or court register, to confirm } \\
\text { the scope of the civil capacity and legal capacity of the } \\
\text { legal entity, the text translated into Ukrainian, the } \\
\text { authenticity of the translator's signature is notarized, } \\
\text { etc. }\end{array}$ \\
\hline
\end{tabular}

Constituent documents submitted to a notary must be notarized at the place of their issuance and duly legalized in consular offices representing Ukraine unless otherwise provided by international treaties of Ukraine.

The Commercial Code of Ukraine states that the activities of branches, representative offices and other separate divisions of enterprises formed under the laws of other states are carried out on the territory of Ukraine following the legislation of Ukraine, i.e. they are also subject to national legal regulation.

Foreign legal entities carry out their activities through branches, representative offices or subsidiaries. Departments and representative offices, unlike subsidiaries, are not legal entities, do not have an independent civil legal personality, but act as separate divisions of the legal entity, represent and protect its interests. On the other hand, subsidiaries have all the characteristics of legal entities but are controlled by the parent company, which exercises control, usually due to the parent company's ownership of a significant amount of corporate rights (shares, stakes, shares) in subsidiaries.

Thus, a foreign legal entity's branch/representative office has no right to act as an independent participant in the transaction.

The National Bank of Ukraine carries out accreditation of branches and representative offices of foreign banks in accordance with the Law of Ukraine "On Banks and Banking". Registration of representative offices of other foreign economic entities is carried out by the central executive body, which ensures the formation and implementation of state policy in the field of economic development (Article 5 of the Law of Ukraine "On Foreign Economic Activity").

The representative's authority to enter into a transaction (contract) may follow from the power of attorney, statutory documents, agreements, and other grounds. If a power of attorney is submitted to a notary on behalf of a foreign legal entity, the procedure for issuance, validity, termination and legal consequences of termination of a power of attorney are determined by the law of the state in which a power of attorney was issued (Article 34 of the Law of Ukraine "On Private International Law").

Documents issued by authorized bodies of foreign states in the prescribed form are recognized as valid in Ukraine if they are legalized unless otherwise provided by law or international treaty of Ukraine (Article 13 of the Law of Ukraine "On Private International Law"). 
Consular legalization of official documents, in accordance with the Instruction on the procedure for consular legalization of official documents in Ukraine and abroad, approved by order of the Ministry of Foreign Affairs of Ukraine from 04.06.2002 №113 and registered by the Ministry of Justice of Ukraine on 26.06 .2002 at №535/6823, there is a procedure for verifying the authenticity of the originals of official documents or verifying the signatures of officials authorized to certify signatures on records, as well as the validity of the stamp and seals attached to the document. Legalization of a document by the established procedure gives it the right to exist in international circulation.

The Consular Service Department of the Ministry of Foreign Affairs of Ukraine does not legalize documents drawn up on foreign states' territory. Such documents must be legalized in the consular office of Ukraine in the country of origin of the documents. In the absence of documents of the consular post of Ukraine in the country of origin, foreign documents may be legalized by the Department of Consular Service of the Ministry of Foreign Affairs of Ukraine, subject to certification in the Ministry of Foreign Affairs of the country of origin and in the consulate of this country.

On December 22, 2003, the Hague Convention (1961) entered into force for Ukraine, abolishing the requirement to legalize foreign official documents. By the provisions of the Hague Convention, the requirement to legalize documents for their further use in the states parties to this convention is abolished. Official documents used in these states' territory must be certified by a unique stamp "Apostille" (, affixed by the competent authority of the state in which the document was drawn up.

Under the second part of Article 3 of the Hague Convention, compliance with the apostille procedure may not be required by States Parties if there are agreements between two or more States which repeal or simplify the process or exempt the instrument itself from legalization.

On November 10, 1994, the Verkhovna Rada of Ukraine ratified the 1993 Convention on Legal Assistance and Legal Relations in Civil, Family and Criminal Matters (Minsk Convention), which entered into force for Ukraine on April 14, 1995, and applies to Ukraine's relations with CIS member states.

According to the provisions of the Minsk Convention, documents that are made or certified by an institution or a specially authorized person within their competence and in the prescribed form and sealed in the territory of one of the states party to the Minsk Convention are accepted on the territory of Ukraine without any what special certificate.

Besides, bilateral international agreements have been concluded between Ukraine and some foreign states, which regulate legal relations and international legal assistance in civil matters and contain provisions that documents drawn up or certified by the competent authority of one Contracting Party and signed by an authorized person official seal, are valid in the territory of the other Contracting Party without further certification. The list of such international agreements that have entered into force to date can be found on the website of the Ministry of Justice of Ukraine.

We also emphasize that the norms of the current international treaty of Ukraine are legally attached to the national legal standards, because, following Art. 9 of the Constitution of Ukraine, existing international treaties, the binding force of which has been approved by the Verkhovna Rada of Ukraine, are part of the national legislation of Ukraine.

Instead, when performing notarial acts, notaries must use the officially published text of the international agreement in the Ukrainian language, provided it is available.

In the absence of an authentic text of the agreement in Ukrainian or an official translation of an international agreement into Ukrainian, it is necessary to use the authentic text of the deal in another official language in which it was concluded. In case of discrepancies between equally authentic texts of the international agreement, the interpretations provided by Art. 33 of the Vienna Convention (Dowgert, 2008)

Thus, the national legislation of Ukraine allows the application of foreign law in the international notarial process but establishes the conditions and limits (restrictions) of their application. The 
establishment of limits on the application of such norms is since the application of foreign law may lead to a violation, in particular, of the constitutional principles established in the Basic Law of Ukraine. Thus, the Law of Ukraine "On Private International Law" and the doctrine of private international law identify several legal mechanisms to prevent the application in Ukraine of foreign law, selected based on the conflict rule. In particular, it is a warning about public order, the effect of mandatory rules of national law, circumvention of the law, reciprocity. Unlike Ukrainian law, the law of foreign countries on private international law adds retaliation to this list.

For example, following Art. 12 of the Law of Ukraine "On Private International Law", the rule of law of a foreign country is not applied in cases where its application leads to consequences that are incompatible with the principles of law and order (public order) of Ukraine. In such cases, the law that has the closest connection with the legal relationship is applied, and if such a right cannot be determined or applied, the law of Ukraine is applied (Karmaza, 2015).

The authors agree with the scientist V. Kysil that the warning about public order (public order, public policy) is contained in the sources of law of almost all legal systems. And although the legal category of "public order" is not new to science and practice, still there is no unambiguous interpretation, a clear definition. Therefore, the meaning of the content of the "pubic order", its purpose is one of the most challenging problems of science and judicial practice (Kisil, 2005).

Notaries and lawyers of Ukraine most often encounter in practice problematic issues related not so much to the legalization of documents issued by the authorized bodies of the state of registration of a legal entity, as the establishment of the time of their validity.

For example, an extract from the commercial, banking or court register to confirm the scope of a legal entity's civil capacity and legal capacity usually has limited validity.

Thus, the question arises as to the validity of such documents' application and validity in Ukraine.

Scientist V. Vasilchenko draws attention to such actions of the participants of legal relations, clarified by a foreign element, as "circumvention of the law". The doctrine of private international law proves that sometimes the parties to the transaction deliberately create a link to foreign law to avoid the application to these legal relations of the coercive law to which they are subject (Vasilchenko, 2007). These are situations when the parties wish to avoid the application of unfavourable or inconvenient from their point of view, the substantive rule of law, and therefore their actions create such a factual composition of legal relations when the applicable law for these relations are selected substantive law of another country parties to the norm (Dowgert, 2008).

\subsection{Restrictions on the activities of legal entities with a foreign element in Ukraine, financial monitoring.}

Statement 3: there are certain restrictions on the activities of legal entities with a foreign element in Ukraine

When certifying transactions involving a foreign legal entity and a foreign enterprise, it should be remembered that the legislation of Ukraine restricts the establishment of foreign enterprises in areas defined by law that are of strategic importance for the security of the state. Foreign legal entities are subject to national law governing legal relations regarding property rights acquisition, with some exceptions. In particular, it is a restriction of the right of non-residents to own agricultural land provided for in Articles 22 and 81 of the Land Code of Ukraine. Agricultural lands may not be transferred to foreign citizens, stateless persons, foreign legal entities and foreign states.

Thus, according to Article 82 of the Land Code of Ukraine, the acquisition of agricultural land by legal entities is not allowed, except in cases of inheritance. However, agrarian land inherited by foreign legal entities is subject to alienation within one year. Concerning non-agricultural lands, foreign legal entities may acquire the right of ownership of land: a) within settlements in the case of acquisition of real estate and for the construction of facilities related to business activities in Ukraine; b) outside the territories in the case of acquisition of real estate. 
There are also offshore companies operating in Ukraine, which is often notarized by a notary due to the inaccessibility in Ukrainian legislation of the relevant jurisdiction on legal entities and the inability to verify the submitted documents. Also, classic offshore companies, which promote the principle of anonymity of foreign investors and confidentiality of information about them, are deservedly considered by law enforcement agencies around the world as a place of registration of legally dubious companies used to achieve illegal goals of their beneficial owners.

The documents based on which the client is identified and verified must be valid at the time of their submission and include all necessary identification data. Copies of documents, except for notarized ones, on the basis of which the notary has established the identification data of the client (client's representative), are certified by a notary, who must inspect the original document, mark the original and affix it with a signature and seal. The notary has the right to demand, and the client, the client's representative is obliged to provide information (official documents) necessary for identification, verification, the study of the client, clarification of information about the client, and also for performance by the notary of other requirements of the legislation legalization (laundering) of proceeds from crime, terrorist financing and financing the proliferation of weapons of mass destruction.

To establish the ultimate beneficial owner (controller), the notary requires the client-legal entity information and/or documents confirming such client's ownership structure.

The notary is also provided with a copy of the legalized extract from the commercial, banking or court register or a notarized registration certificate of the foreign state's authorized body on the registration of the relevant legal entity.

The trust notary must additionally find out the identification data of the principals and proxies.

A risk assessment by the geographical location of the country of registration of the client or institution is carried out about the client or institution country of origin and/or registration of which, country of receipt or transfer of funds (which), country of location of the counterparty bank, country of origin, country of registration from reliable sources it is known that it:

- fails to implement or improperly implements the recommendations of international, intergovernmental organizations involved in the fight against money laundering or terrorist financing;

- included by the Cabinet of Ministers of Ukraine in the list of offshore zones;

- supports international terrorist activities.

\subsection{Using ICT technologies for identifying transactions involving entities with foreign elements.}

Statement 4: the use of ICT technologies in transactions with the participation of entities with foreign elements is a necessity of modern society

As for the digital age in jurisprudence, the notary has always been at its cutting edge. Notaries were among the first to work with electronic registers, and it was thanks to notaries that the registration mechanism was launched in the state. In the coming decades, new technologies will by no means replace notaries. However, they are able to improve and simplify the notarial process. Digitization is not a goal, but a perfectly acceptable tool.

The introduction of ICT technologies into the notarial practice, such as the remote format of certification of transactions, the use of programming languages, is a logical innovation that meets society's modern needs.

Due to the peculiarities of the transactions' subjects, the remote format of certification of transactions is the most urgent. In many foreign countries (for example, France), this processing transaction practice has been working successfully for a long time and is in demand among the population. With the distances between the regions of Ukraine, not always stable and convenient transport links, it is possible to conclude a deal without unnecessary and costly movements. It is also relevant in the context of a high level of internal migration of citizens: when some, for example, want 
to buy housing in a large city, using the real estate they inherited in the region as initial capital, while others, on the contrary, sell housing in a metropolis to relocate to a more spacious one, but in a smaller settlement.

At the same time, the very procedure for contacting a notary for the parties to a transaction in the case of a remote version of its certification, in fact, is not much different from the traditional option, when all parties to the agreement gather in one notary office. The only condition that must be taken into account when it comes to a real estate transaction is that one of the notaries must be located in the region where the object of the transaction is located.

In short, the choice in favour of the remote transaction format does not entail any additional difficulties for citizens, on the contrary, at least initial consultations a notary can and should conduct online using the video conferencing format - GoogleMeet, Zoom and the like.

Unfortunately, this practice is not regulated by law, therefore, it can become a further developed specifically for the development of recommendations for the development of legislative acts.

The process might look like this. Each party to the transaction chooses a notary office convenient for themselves in their country/city, where they will conduct the transaction. Further, each of the notaries conducts a standard list of checks, which is provided by law as part of the notarization of the transaction. It will establish the identity of the applicant, conduct an examination of the documents, check the real will of the person, the awareness and voluntariness of his actions, and explain the legal essence and consequences of the contract. After agreeing the time with each other, the parties to the transaction come to an appointment, each to his own notary. Further, the draft agreement, already agreed with the applicants, is entered into the Electronic Register of Notaries.

With regard to the process of signing a document, then in the remote version for applicants, the use of so-called simple electronic signatures is provided. The bottom line is that the parties to the transaction sign-on special tablets, which are provided to them by notaries. Thus, the execution of a transaction through a notary a priori eliminates the need to purchase personal ones. Enhanced qualified electronic signatures of notaries will give legal force to such an agreement in digital form. As a result, the data on the transaction is recorded in the Electronic Register of Notaries.

Digitization of notarial activities should also provide in the future:

- refusal to keep paper books of accounting of the notary's activity;

- reducing the number of documents that a person must submit to perform a notarial act;

- automation of a number of processes in the activities of notaries;

- effective information interaction between state information resources;

- maintaining a notarial archive in electronic form.

In Ukraine, the SMS-Maiak service has already started working in demo mode, which can protect real estate, land plots or mortgage objects from unauthorized raider seizures. He reports not only on the changes that have taken place but also on attempts to make such changes. IT service is also available in the LIGA360 ecosystem.

\subsection{The tax burden on a legal entity with a foreign element.}

Statement 5: Law of Ukraine of 16.01.2020 № 466-IX "On Amendments to the Tax Code of Ukraine to improve tax administration, eliminate technical and logical inconsistencies in tax legislation" introduces some changes in taxation in Ukraine of LEFE.

An essential issue in the organization of investment activities and risk assessment of economic activity in Ukraine is the analysis of the tax burden on a legal entity with a foreign element. For example, the legislation of Ukraine stipulates the Buyer's obligation to pay the Mandatory State Pension Insurance Fee, the payment of which is provided by the Law of Ukraine "On Mandatory State Pension Insurance Fee" № 400/97 - VR of June 26, 1997, in the amount of 1 per cent of the value of real estate specified in the contract of sale and payment - the tariff of the state duty, namely 1 per 
cent of the price by Article 3 of the Decree of the Cabinet of Ministers of Ukraine "On State Duty" for № 7-93 of January 21, 1993.

Following paragraph 9 of Art. 1 of the Law of Ukraine "On the fee for mandatory state pension insurance" № 400/97 - VR of 26.06.1997 with changes and additions payers of the fee for mandatory state pension insurance are: enterprises, institutions and organizations regardless of ownership and physical persons acquiring real estate, except for state enterprises, institutions and organizations acquiring real estate at the expense of budget funds, institutions and organizations of foreign states, enjoying immunities and privileges following the laws and international treaties of Ukraine, consent to the binding nature of which provided by the Verkhovna Rada of Ukraine, as well as citizens who purchase housing and are in the queue for housing or purchase housing for the first time. Thus, LEFE are not exempt from paying $1 \%$ of the fee for mandatory state pension insurance.

It is worth noting that from 01.01.2017 Ukraine joined the Action Plan BEPS (Base Erosion and Profit Shifting) - an international project of the Organization for Economic Cooperation and Development (OECD) and the G20 to develop measures to combat the decline of the tax base and withdrawal of profits from taxation, which in 2020 led to the so-called "Revolution in taxation" of foreigners in Ukraine (Law of Ukraine, 2019).

The implementation of the BEPS Action Plan is driven by the need to develop a single multilateral mechanism to combat aggressive tax planning aimed at artificially reducing the tax base and shifting taxable profits to low-tax jurisdictions.

The expected effect of this project is the establishment of a uniform, transparent tax rules for all countries (jurisdictions) to prevent tax evasion by businesses. Today, 137 countries (jurisdictions) are participants in the project.

The result of the so-called "Tax Revolution" is the entry into force of the Law of Ukraine dated 16.01.2020 № 466-IX "On Amendments to the Tax Code of Ukraine to improve tax administration, eliminate technical and logical inconsistencies in tax legislation." Thus, this Law is aimed at the implementation of eight actions of the BEPS Plan in Ukraine.

To fully disclose the authors of the research topic and interesting for the analysis of taxation in Ukraine of LEFE is action 3 BEPS "Development of effective rules of taxation of controlled foreign companies", namely crucial innovations are the definition of legal and de facto control of foreign legal entities partial establishment by legal entities or individuals-residents of Ukraine:

"Income of foreign legal entities and entities without the status of a legal entity (in particular, partnerships, trusts, funds, other institutions and organizations) may be taxed in Ukraine if such persons are under legal/actual control of individuals/legal entities-residents of Ukraine". The presence of legal control is established if a natural/legal person-resident of Ukraine owns a share in a foreign legal entity in the amount of more than $50 \%$ or more than $10 \%$, provided that several natural/legal persons-residents of Ukraine own shares in such foreign legal entity, the size of which is a total of 50 per cent or more.

The availability of actual control is determined in particular, but not exclusively, by the following criteria:

- a natural person/entity - a resident of Ukraine, conducts negotiations and agrees on the essential terms of transactions, which are formally approved or performed by the governing bodies of a controlled foreign company (CFC) without further approval;

- a natural person/entity - a resident of Ukraine, carries out operations on bank accounts of KIK or has the opportunity to block operations on such accounts;

- a natural person/entity - a resident of Ukraine has a power of attorney to carry out significant transactions on behalf of the CFC, issuance and a term of more than one year, which does not provide for prior approval of such transactions by the authorities of the CFC;

- a natural person/entity - a resident of Ukraine, specified as the founder (beneficiary, actual beneficiary) of the CFC when opening accounts of such CFC. 
In conclusion, it should be noted that the taxpayer of income of the CFC is the controlling person, i.e. a natural/legal person - a resident of Ukraine, who exercises control over the CFC. The object of taxation for personal income tax (corporate income tax) is a part of the adjusted profit of the CFC, proportional to the share owned or controlled by the controlling person (KPMG, 2020).

These innovations will come into force on 01.01.2021, so the analysis of the effectiveness of the practical aspect of the application of the above tax rules will be carried out later. Under pressure from the international community, the legislature aims to bring CFC revenues out of the shadows, but in-depth control makes it easy to drive them there.

\section{Discussion.}

Thus, to summarize the above statements, it is possible to represent the actions of a notary in the form of an algorithm of actions (Fig. 1).

Figure 1. Algorithm of actions of a notary to certify transactions involving LEFE

\begin{tabular}{|l|l|l|l|} 
Check whether... \\
foreign legal entity or with the participation of non-residents, but under \\
the legislation of Ukraine
\end{tabular}

This diagram clearly provides explanations for notaries to avoid mistakes.

\section{Conclusions.}

Summarizing the above, we note that the task of the notary in certifying transactions involving LEFE is not only to properly apply foreign law in the international notarial process as it is applied in a foreign country but also to establish no limits of application and compliance with the national law of Ukraine.

A separate issue is the study of the presence in the actions of foreign legal entities signs of circumvention of the law, which in legal science and practice has no straightforward solution, is debatable and requires additional thorough research, restriction of autonomy under Ukrainian law, and compatibility of consequences application of norms of foreign law with the principles of public order of Ukraine, clarification of the existence of imperative norms in the Laws of Ukraine, which must be applied independently of foreign law.

The authors support scholars who propose, taking into account the features defined by the Law of Ukraine "On Private International Law", to supplement the Procedure for notarial acts by notaries of Ukraine with a separate section on the establishment and application of foreign law. The list of 
documents submitted to the notary by LEFE needs to be regulated in more detail to establish the scope of civil legal capacity and legal capacity of such legal entity.

The use of ICT technologies in notaries can not only simplify the process, help avoid subjective mistakes, but also open up new opportunities to simplify transactions involving entities with foreign elements.

The result of the article and its novelty is a detailed study of a notary's actions in the certification of transactions involving LEFE, the presentation of a visual algorithm and a detailed description of the nuances to avoid possible errors.

\section{References}

1. Christie, A. (2017). Private International Law Principles for Ubiquitous Intellectual Property Infringement - a Solution in Search of a Problem? Journal of Private International Law, 13(1), pp. 152-183.

2. Civil Code of Ukraine of January 16,2003 , as amended.

3. Dolynska, M. (2018). Theoretical-legal and applied aspects of the notarial procedure concerning the certification of wills. In book: Development trends in legal science and practice: the experience of countries of Eastern Europe and prospects of Ukraine, DOI: 10.30525/978-9934-571-29-9_4

4. Dorofeeva, Y.A. (2021). Foreign Law in the Relations Paradigm Involving a Foreign Element. In: Economic Systems in the New Era: Stable Systems in an Unstable World. IES 2020. Lecture Notes in Networks and Systems, Ashmarina S.I., Horák J., Vrbka J., Šuleř P. (eds), 160. Springer, Cham. DOI: 10.1007/978-3-030-60929-0_15

5. Economic Code of Ukraine of January 16, 2003, as amended.

6. Fursa, S. (2012). Teoriia notarialnoho protsesu: Naukovo-praktychnyi posibnyk [Theory of the notarial process: Scientific and practical manual], Kyiv: Alerta, 920 p. (in Ukrainian).

7. Karmaza, O. (2015). Problemy zastosuvannia v notarialnomu protsesi norm inozemnoho prava. [Problems of application of foreign law in the notarial process]. Naukovyi visnyk Khersonskoho derzhavnoho universytetu. [Scientific Bulletin of Kherson State University]. Series: Legal Sciences.,4 (1), pp. 110-114. (in Ukrainian).

8. Kisil, V. (2005). Mizhnorodne pryvatne pravo: pytannia kodyfikatsii. [International private law: issues of codification], Ukraine, 480 p. (in Ukrainian).

9. Komarov, V., Barankova, V. (2011). Notariat v Ukraini: Pidruchnyk [Notary in Ukraine: Textbook], Kharkiv: "Pravo". "Law", 384 p. (in Ukrainian).

10.KPMG (2020). Zminy u podatkovomu zakonodavstvi Ukrainy cherez poshyrennia COVID-19 [Changes in the tax legislation of Ukraine due to the spread of COVID-19]. Retrieved from https://home.kpmg/ua/uk/home/insights/2020/03/tax-and-legal-considerations.html (accessed on December 10, 2020) (in Ukrainian).

11.Law of Ukraine "On Foreign Economic Activity" of 16.04.1991 № 959-12 as amended and supplemented.

12.Law of Ukraine "On Notaries" of 02.09.1993 № 3425 - XII with changes and additions.

13.Law of Ukraine "On Prevention and Counteraction to Legalization (Laundering) of Proceeds from Crime, Financing of Terrorism and Financing of Proliferation of Weapons of Mass Destruction" of December 6, 2019 № 361-IX.

14.Law of Ukraine "On Private International Law" of June 23, 2005 № 2709-IV as amended and supplemented.

15.Law of Ukraine “On the Foreign Investment Regime” of March 19, 1996 № 93/96-VR. 
16.Letter of the Supreme Specialized Court of Ukraine for Civil and Criminal Cases "On the practice of consideration by courts of civil cases with a foreign element" dated 16.05.2013 № 24-754/0/ 413.

17.Merkulova, S. (2020). Notarialnyie deystviya kak sredstva obespecheniya i zaschityi prav i zakonnyih interesov grazhdan [Notarial Acts as Means of Ensuring and Protecting the Rights and Legal Interests of Citizens], PRAVO: istoriya i sovremennost [LAW: history and modernity], 1, pp. 16-22. DOI: 10.17277/pravo.2020.01.pp.016-022 (in Russian).

18. Mizhnarodne pryvatne pravo. Naukovo-praktychnyi komentar Zakonu [Private international law. Scientific and practical commentary on the Law] / ed. prof. A. Dowgert: LLC "Odyssey", 2008, 352p. (in Ukrainian).

19.Nahnybida, V. (2020). Problemy vyznachennia inozemnoho elementu pry vyrishenni sporiv u mizhnarodnomu komertsiinomu arbitrazhi [Problems of determining a foreign element in dispute resolution in international commercial arbitration]. Chasopys Kyivskoho universytetu prava. [Law Review of Kyiv University of Law], (1), 361-365. DOI: 10.36695/2219-5521.1.2020.72 (in Ukrainian).

20.Nani, L. (2018). Tax regulation with a foreign element in the republic of Moldova. Journal of Foreign Legislation and Comparative Law, 4(5), pp. 57-62. DOI: 10.12737/art.2018.5.9

21.Pieprzyca, P. (2016). Notarial act as a performative utterance. Comparative Legilinguistics, 25, pp. 27-40. DOI: $10.14746 / \mathrm{cl} .2016 .25 .02$

22.Rogerson, P. (2015). Problems of the applicable law of the contract in the English common law jurisdiction rules: the good arguable case. Journal of Private International Law, 9(3), pp. 387-411.

23.Vasilchenko, V. (2007). Scientific and practical commentary on the Law "On Private International Law", Kyiv: Truth, 200 p.

24.Zhang, M. (2018). Enforceability: Foreign Arbitral Awards in Chinese Courts. San Diego International Law Journal, 20, pp. 1-70. 